\title{
Review
}

\section{Helicobacter pullorum: A potential hurdle emerging pathogen for public health}

\author{
Wafaa A Abd El-Ghany ${ }^{1}$ \\ ${ }^{1}$ Poultry Diseases Department, Faculty of Veterinary Medicine, Cairo University, Egypt
}

\begin{abstract}
Emerging zoonotic pathogens gain more attention due to the adverse effects on human and animal's health and productivity. One of these zoonotic pathogens is Helicobacter pullorum (H. pullorum) which was firstly diagnosed in 1994. This bacterium is enterpathogenic in poultry and contaminates the carcasses meat during processing or improper handling. Human can get H. pullorum infection mainly through mishandling of contaminated carcasses or consumption of undercooked meat. Infection of H. pullorum in human is associated with gastroenteritis and hepatitis. Diagnosis of $H$. pullorum is very difficult as misdiagnosis with other enteric zoonotic pathogens like Campylobacter and other Helicobacter species is common. Unlike other types of Helicobacter, there are little information and few researches regarding prevalence, pathogenesis, diagnosis and control of $H$. pullorum infection either animals or human. Accordingly, this review article was prepared to give more details about $H$. pullorum sources of infection, pathogenicity, incidence in poultry and human as well as its treatment.
\end{abstract}

Key words: H. pullorum; human; poultry; public health; zoonosis.

J Infect Dev Ctries 2020; 14(11):1225-1230. doi:10.3855/jidc.12843

(Received 18 April 2020 - Accepted 28 July 2020)

Copyright (C) 2020 Abd El-Ghany et al. This is an open-access article distributed under the Creative Commons Attribution License, which permits unrestricted use, distribution, and reproduction in any medium, provided the original work is properly cited.

\section{Introduction}

Emerging disease is that caused by new etiological agent previously known but now occurring in species or places where the disease was unknown [1]. Infection with Helicobacter species is considered as one of these emerging diseases. Genus Helicobacter is belonging to class Epsilonproteobacteria that was established in 1989. These pathogens are divided into two groups, gastric and enterohepatic, based on their preferred site of colonization [2] and also on 16S rRNA sequence data. More than 30 species of Helicobacter have been recorded in the last two decades [3]. One of these newly identified species is Helicobacter pullorum ( $H$. pullorum). This pathogen is fastidious, microaerophilic, non-sporulated and Gram-negative spirally curved motile bacillus with monopolar flagellae [2]. It has been considered that $H$. pullorum is an enterohepatic Helicobacter species [4]. This bacterium has been early discovered from the intestine and liver of diarrheic birds $[5,6]$ as well as from the faeces and biopsies of patients with gastroenteritis, chronic liver disease and inflammatory bowel disease [7]. H. pullorum has a zoonotic potential [8-12] as it has been associated with approximately $12 \%$ of human zoonotic cases [13]. Consumption of undercooked or surface contaminated chicken is considered as a potential route of
Helicobacter transmission to human beings [14]. Susceptibility of avian and animal species as well as human beings to $H$. pullorum is variable. Infections with $H$. pullorum were recorded in different avian species like chickens, turkeys, ostriches, Guinea fowl, parrots and psittacine birds $[15,16]$, rabbits and rodents [17-19] and human [20]. Limited sources of data concerning $H$. pullorum infection in different species and their relations to human infection are available. Thus, in this review article, we will investigate $H$. pullorum sources of infection, pathogenicity, incidence in poultry and human as well as the possible treatment of this pathogen.

\section{Sources of infection}

The sources of $H$. pullorum infection to human is summarized in Table 1. Avian species serve as potent reservoirs for $H$. pullorum [21]. There is an association between $H$. pullorum presence in the intestinal tract of poultry with diarrhea and vibrionic hepatitis as well as presence of pathogen in patients with diarrhea, vomiting and liver and gallbladder diseases $[2,7,22]$. Surface contamination of broiler chickens' carcasses with the caecal contents during processing and handling is common [2,5]. It has been detected that $H$. pullorum colonizes the caecum of broilers and is excreted in the 
droppings till slaughtering and this implies that chicken meat constitutes a major source of infection for human [23]. Therefore, H. pullorum is considered as a pathogen of food borne significance [24,25]. In Australia, $H$. pullorum was isolated from chicken meat in the rate of $13.5 \%$ [26]. Furthermore, González et al. [27] identified H. pullorum in 3 types of chicken's meat products with $99 \%$ genetic match. Similarly, Borges et al. [10] in Italy demonstrated that the emerging $H$. pullorum pathogen can be transmitted to humans by chicken meat consumption and/or contact as the organism was isolated from 4 out of 17 (23.5\%) fresh chicken meat samples from different producers.

It should be noted that, not only poultry meat is the source of $H$. pullorum infection for human, but also table eggs are another source. A total of 300 commercial chicken eggs were collected from Assiut and Qena governorates in Egypt for the presence of Helicobacter species detection [4]. The authors found that $H$. pullorum contamination rate of egg contents was $6.6 \%$ in Assiut and 3.3\% in Qena governorate. Regarding the sources of chicken's infection in the farms, the study of Wai et al. [6] proved existence of $H$. pullorum in $17.5 \%$ of the house flies and $30 \%$ of the house floors in the farms of Malaysia. Moreover, Ceelen et al. [7] isolated H. pullorum from farmers' boots which is regarded as another mechanical source of infection. Concurrent presence of Helicobacter and Campylobacter species in cats has been reported [28] and water contamination with Helicobacter organisms was also demonstrated [29].

\section{Pathogenesis}

After infection of the host with $H$. pullorum, the bacterium adheres to the microvilli of the intestinal epithelial cells via flagellae for colonization and invasion. Consequently, this invasion induces cellular damage, debris and oedema [30]. In addition, adhesion of the pathogen to the intestinal surface stimulates the production and release of inflammatory substances like IL-8. The inflammatory process is more triggered through production of cytolethal distending toxin and lipopolysaccharide [7]. It has been reported that infection with $H$. pullorum activates the host's macrophages and secretion of cytokines (TNF- $\alpha$, IL-1 $\beta$, IL-6 and MIP-2) as well as production of nitric oxide in murine macrophages [31]. However, Yanagisawa et al. [32] depicted that $H$. pullorum infected human hepatocytes and bile duct and colon epithelial cells displayed increased expression of matrix metalloproteinases 2, 7 and 9 which help in degradation of extracellular matrix and allowing the pathogen to interact with host cells.

\section{Incidence of infection}

The incidence of $H$. pullorum in poultry and human in different countries is present in Table 2.

\section{Poultry}

Early study in Switzerland demonstrated $H$. pullorum in the caecal contents of 150 apparently healthy broiler chickens (4\%) and in 9 out of 18 caeci of layers with vibrionic hepatitis [33]. Also, in broiler chickens with Campylobacters and Archobacters, $H$. pullorum was identified from 9 out of 15 frozen cecum $(60 \%)$ and 9 out of 15 fresh carcasses $(60 \%)$ [34]. The molecular identification results using Polymerase Chain Reaction (PCR) demonstrated presence of $H$. pullorum in $33.6 \%$ of the caecum and in $4.6 \%$ of the liver from 110 examined broiler chickens in Belgium [35]. In Italy, Zanoni et al. [36] investigated presence of $H$. pullorum in the caecal contents of 60 chickens that representing 9 broiler and 6 laying chickens' farms. On the other hand, PCR results showed that 42 out of 55 animals (76.4\%) and 11 farms of turkeys were positive for H. pullorum [37]. Chickens reared in free-range

Table 1. Sources of $H$. pullorum infection to human.

\begin{tabular}{|c|c|}
\hline Sources of $\boldsymbol{H}$. pullorum infection to human & Reference \\
\hline All avian species & Andersen [21] \\
\hline The intestinal tract of poultry & Stanley et al. [2], Ceelen et al. [7], Fox et al. [22] \\
\hline $\begin{array}{l}\text { Surface contamination of the chicken } \\
\text { carcasses by the caecal contents }\end{array}$ & Ceelen et al. [23] \\
\hline $\begin{array}{l}\text { Contamination of hands during handling of } \\
\text { the processed chicken carcasses }\end{array}$ & Stanley et al. [2], Atabay et al. [5] \\
\hline Chicken meat & Borges et al. [10], On et al. [24], Gibson et al. [25], Miller et al. [26], González et al. [27] \\
\hline Table eggs & Abdel Hameed and Sender [4] \\
\hline House flies and house floors & Wai et al. [6] \\
\hline Farmers' boots & Ceelen et al. [7] \\
\hline Cats & Shen et al. [28] \\
\hline Water contamination & Azevedo et al. [29] \\
\hline
\end{tabular}


farms had lower occurrence $(57 \%)$ of $H$. pullorum compared to birds reared in conventional $(84 \%)$ and organic (97\%) farms [38]. The work undertaken by Wai et al. [39] in Selangor and Malaysia identified $H$. pullorum from broiler chickens with $24.72 \%$ prevalence rate, where $12.36 \%$ of chickens showed concomitant infection with Campylobacter. Recently, the same author recognized $H$. pullorum in $51 \%$ of caeca of 100 chickens collected from processing sites or markets [6]. In Marmara region of Turkey, $H$. pullorum incidence rate was $55.21 \%$ after testing of 12 broiler chicken flocks [40]. Iranian study of Shahram et al. [20] showed that out 120 diarrheic broiler chicken, H. pullorum prevalence rates were $7.5 \%$ (intestinal swabs), $5 \%$ (liver) and 2.5\% (thigh meat). However, higher prevalence rate $(61 \%)$ of $\mathrm{H}$. pullorum was also detected in Iran from 100 caecal samples of broiler chickens [41]. The highest incidence of $H$. pullorum in chickens were recorded in many countries where it ranged from $60 \%$ in the UK [42] to $78.3 \%$ in Czech Republic [43] and 100\% in Italy [10] and France [44].
In Egypt, few researches have been conducted to detect the prevalence of $H$. pullorum among different types of living poultry as well as poultry products. A big study has been done in Assuit Province, where 1800 samples were collected from cloacal swabs, caecal contents and liver of chickens, turkeys and ducks' flocks [45]. The results revealed identification of 100 isolates of $H$. pullorum from chickens with a percentage of $39.33 \%$. Although the main niche for colonization of H. pullorum is the intestine especially the caecum, but Hassan et al. [16] proved presence of the pathogen also in the liver tissues of the birds. Moreover, the study of Hassan et al. [46] demonstrated that out of 900 cloacal, caecal and liver tissues of broiler chickens, the incidence rate of $H$. pullorum was $39.33 \%$ using species-specific 16S rRNA PCR. Experimentally inoculated broilers with $H$. pullorum elicited 33.3\% mortalities with signs of diarrhea, retardation of growth with poor conversion rate and the pathogen was reisolated from the caecum, liver, yolk sac and air-sacs of dead and sacrificed chickens [46].

Table 2. Incidence of $H$. pullorum in poultry and human.

\begin{tabular}{|c|c|c|}
\hline Country & Findings & Reference \\
\hline Switzerland & $\begin{array}{l}\text { H. pullorum was detected in the caecal contents of } 150 \text { apparently healthy } \\
\text { broiler chickens }(4 \%) \text { and in } 9 \text { out of } 18 \text { caeci of layers }\end{array}$ & Burnens et al. [33] \\
\hline \multirow[t]{2}{*}{ Belgium } & $\begin{array}{l}\text { H. pullorum was molecularly identified in } 33.6 \% \text { of the caecum and in } 4.6 \% \text { of } \\
\text { the liver from } 110 \text { examined broiler chickens }\end{array}$ & Ceelen et al. [35] \\
\hline & $\begin{array}{l}\text { H. pullorum was detected in the clinically healthy persons and the patients with } \\
\text { gastroenteritis in percentages of } 4 \% \text { and } 4.3 \% \text {, respectively }\end{array}$ & Ceelen et al. [7] \\
\hline \multirow[t]{2}{*}{ Italy } & $\begin{array}{l}\text { H. pullorum was present in the caecal contents of } 60 \text { chickens that representing } \\
9 \text { broiler and } 6 \text { laying chickens' farms }\end{array}$ & Zanoni et al. [36] \\
\hline & H. pullorum was isolated from chickens in incidence of $100 \%$ & Borges et al. [10] \\
\hline \multirow[t]{2}{*}{ Malaysia } & $\begin{array}{l}\text { H. pullorum was isolated from broiler chickens with } 24.72 \% \text { prevalence rate, } \\
\text { where } 12.36 \% \text { of chickens showed concomitant infection with Campylobacter }\end{array}$ & Wai et al. [39] \\
\hline & $\begin{array}{l}\text { H. pullorum in } 51 \% \text { of caeca of } 100 \text { chickens collected from processing sites or } \\
\text { markets }\end{array}$ & Wai et al. [6] \\
\hline Turkey & $\begin{array}{l}\text { H. pullorum incidence rate was } 55.21 \% \text { after testing of } 12 \text { broiler chicken } \\
\text { flocks }\end{array}$ & Beren and Seyyal [40] \\
\hline \multirow[t]{3}{*}{ Iran } & $\begin{array}{l}\text { Out } 120 \text { diarrheic broiler chicken, } H \text {. pullorum prevalence rates were } 7.5 \% \\
\text { (intestinal swabs), } 5 \% \text { (liver) and } 2.5 \% \text { (thigh meat) }\end{array}$ & Shahram et al. [20] \\
\hline & $\begin{array}{l}\text { The prevalence rate of } H \text {. pullorum was } 61 \% \text { from } 100 \text { caecal samples of } \\
\text { broiler chickens }\end{array}$ & Jamshidi et al. [41] \\
\hline & $\begin{array}{l}\text { Six positive cases of } H \text {. pullorum was detected in } 100 \text { stool samples of patients } \\
\text { with gastroenteritis }\end{array}$ & Shahram et al. [20] \\
\hline United Kingdom & H. pullorum was isolated from chickens in incidence of $60 \%$ & Sergeant et al. [42] \\
\hline Czech Republic & H. pullorum was isolated from chickens in incidence of $78.3 \%$ & $\begin{array}{l}\text { Svobodova and Boribova } \\
{[43]}\end{array}$ \\
\hline France & H. pullorum was isolated from chickens in incidence of $100 \%$ & Pilon et al. $[44]$ \\
\hline \multirow[t]{3}{*}{ Egypt } & $\begin{array}{l}\text { Identification of } 100 \text { isolates of } H \text {. pullorum from cloacal swabs, caecal } \\
\text { contents and liver of chickens with a percentage of } 39.33 \%\end{array}$ & Mohamed et al. [45] \\
\hline & $\begin{array}{l}\text { Out of } 900 \text { cloacal, caecal and liver tissues of broiler chickens, the incidence } \\
\text { rate of } H . \text { pullorum was } 39.33 \%\end{array}$ & Hassan et al. [46] \\
\hline & $\begin{array}{l}\text { Experimental infection with } H \text {. pullorum in chickens elicited } 33.3 \% \text { mortalities } \\
\text { with signs of diarrhea, retardation of growth with poor conversion rate and the } \\
\text { pathogen was re-isolated from the caecum, liver, yolk sac and air-sacs of dead } \\
\text { and sacrificed chickens }\end{array}$ & \\
\hline
\end{tabular}




\section{Human}

Diarrhea caused by infectious agent is a major cause of worldwide morbidity and mortality in human, especially in children [47]. There are some reports suggesting that $H$. pullorum is a major pathogen of human. Early, H. pullorum was first isolated from the stool of a male patient with diarrhea and elevated liver enzymes [48]. Later on, this pathogen was discovered from faeces of diarrheic patients, 3 months after the onset of symptoms [49]. Infection of human with $H$. pullorum is not only associated with gastroenteritis and diarrhea, but also with gall bladder and liver diseases [22]. In addition, H. pullorum was isolated from 35 year old male suffering from bacteraemia, abdominal pain and profuse diarrhea [50]. In 2005, H. pullorum was detected in the clinically healthy Belgium persons and the patients with gastroenteritis in percentages of $4 \%$ and $4.3 \%$, respectively [7]. They concluded that presence of $H$. pullorum in the stool of apparently healthy individuals may indicate that this bacterium is harmless normal inhabitant in the intestine or it proliferates after consumption of contaminated food. They also assumed that certain unknown predisposing factors may change non-pathogenic normal intestinal $H$. pullorum to highly virulent pathogenic ones. $H$. pullorum has also been identified by PCR in humans with inflammatory bowel disease $[41,51]$, viral hepatitis C [52-54], cholecystitis [55,56] and hepatocellular carcinoma [57,58]. Another study of Shahram et al. [20] recognized 6 positive cases of $H$. pullorum from 100 stool samples of patients with gastroenteritis in Ardabil province, Iran. It was also found that $H$. pullorum may have an important role in Crohn's disease caused by Mycobacterium paratuberculosis in inflammatory bowel disease $[59,60]$.

\section{Treatment}

Unfortunately, there is no recommended groups of drugs for treatment of $H$. pullorum infection. The sensitivity or resistance of $H$. pullorum isolates to different antimicrobials have been studied with variable results. The in-vitro resistance of avian $H$. pullorum isolates to nalidixic acid revealed percentages of $6 \%$ [24] and 26\% [5]. Moreover, resistance of H. pullorum to cephalothin and cefoperazone was also recorded [2, 24,36]. Recently, tetracycline resistance of $H$. pullorum mutant strain was recorded [10]. Conversely, $H$. pullorum was found to be susceptible to polymyxin B [5]. Moreover, human strains of $H$. pullorum displayed sensitivity to aminoglycosides, third-generation cephalosporins, $\beta$-lactams and doxycycline [50]. In Upper Egypt, high incidence of avian $H$. pullorum resistance to ciprofloxacin, gentamicin and erythromycin followed by tetracycline were observed $[45,46]$. Nevertheless, the same studies revealed high sensitivity of the pathogen to ampicillin and/or colistin sulfate suggesting them as drugs of choice for treatment of infection in chickens. The study of Abdel Hameed and Sender [4] indicated that $H$. pullorum isolated from chickens' eggs were resistant to ampicillin, ceftriaxone and sulphamethoxazole trimethoprim in-vitro.

\section{Conclusion}

It has been considered that $H$. pullorum is an emerging pathogen of potential zoonotic importance for both human and animals. Little is known about this bacterium infection. So, more extensive attention and studies should be carried out to increase the knowledge and information about $H$. pullorum prevalence, infectivity and control measures. The closed-housing system with good biosecurity, management and husbandry practices could reduce and control the presence of $H$. pullorum in in the farms. It is important to focus on the methods of control of this pathogen at the farm level till retailing. These data will have a public health importance in relation to reducing human exposure associated with the handling and consumption of contaminated processed chicken's meat.

\section{References}

1. Meslin FX (1992). Surveillance and control of emerging zoonoses. World Health Stat Q 45: 200-207.

2. Stanley J, Linton D, Burnens A, Dewhirst FE, On SL, Porter A, Owen RJ, Costas M (1994) Helicobacter pullorum sp. novgenotype and phenotype of a new species isolated from poultry and from human patients with gastroenteritis. Microbiology 140: 3441-3449.

3. On SLW, Hynest S, Wadström T (2002) Extragastric Helicobacter species. Helicobacter 7: 63-67.

4. Abdel Hameed KG, Sender G (2011) Prevalence of Helicobacter pullorum in Egyptian hen's eggs and in vitro susceptibility to different antimicrobial agents. Anim Sci Papers Reports 29: 257-264.

5. Atabay HI, Corry JEL, On SLW (1998) Identification of unusual Campylobacter-like isolates from poultry products as Helicobacter pullorum. J Appl Microbiol 84: 1017-1024.

6. Wai SS, Abdul-Aziz S, Bitrus AA, Zunita Z, Abu J (2019). Helicobacter pullorum in broiler chickens and the farm environment: A one health approach. Int J One Health 5: 20 25.

7. Ceelen L, Decostere A, Verschraegen G, Ducatelle R, Haesebrouck F (2005) Prevalence of Helicobacter pullorum among patients with gastrointestinal disease and clinically healthy persons. J Clin Microbiol 43: 2984-2986.

8. Young VB, Chine CC, Knox KA, Taylor NS, Schauer DB, Fox JG (2000) Cytolethal distending toxin in avian and human isolates of Helicobacter pullorum. J Infect Dis 182: 620-623. 
9. Pellicano R, Mazzaferro V, Grigioni WF, Cutufia MA, Fagoonee S, Silengo L, Pizzetto M, Ponzetto A (2004) Helicobacter species sequences in liver samples from patients with and without hepatocellular carcinoma. World J Gastroenterol 10: 598-601.

10. Borges V, Santos A, Correia CB, Saraiva M, Ménard A, Vieira L, Sampaio DA, Pinheiro M, Gomes JP, Oleastro M (2015) Helicobacter pullorum isolated from fresh chicken meat: antibiotic resistance and genomic traits of an emerging foodborne pathogen. Appl Environ Microbiol 81: 8155-8163. 5 .

11. Javed S, Gul F, Javed K, Bokhari H (2017) Helicobacter pullorum: An emerging zoonotic pathogen. Front Microbiol 8: 604.

12. Mladenova-Hristova I, Grekova O, Patel A (2017) Zoonotic potential of Helicobacter spp. J Microbiol Immunol Infect 50: 265-269.

13. Taylor LH, Latham SM, Woolhouse ME (2001) Risk factors for human disease emergence. Philos Trans R Soc Lond B Biol Sci 356: 983-989.

14. Wesley IV (2001) Arcobacter and Helicobacter. In: Labbe G, Garcin S Editors, Guide to Foodborne Pathogens. New York: A John Wiley and Sons, Inc., 23-34.

15. Nebbia P, Tramuta C, Ortoffi M, Bert E, Cerruti S, Robino P (2007) Identification of enteric Helicobacter in avian species. Schweiz Arch Tierheilkd 149: 403-407.

16. Hassan A, Shahata M, Refaie E, Ibrahim R (2014) Detection and identification of Helicobacter pullorum in poultry species in Upper Egypt. J Adv Vet Res 4: 42-48.

17. Van den Bulck K, Decostere A, Baele M, Marechal M, Ducatelle R, Haesebrouck F (2006) Low frequency of Helicobacter species in the stomachs of experimental rabbits. Lab Anim 40: 282-287.

18. Boutin SR, Shen Z, Roesch PL, Stiefel SM, Sanderson AE, Multari HM, Pridhoko EA, Smith JC, Taylor NS, Lohmiller JJ, Dewhirst FE, Klein HJ, Fox JG (2010) Helicobacter pullorum outbreak in $\mathrm{C} 57 \mathrm{BL} / 6 \mathrm{NTac}$ and $\mathrm{C} 3 \mathrm{H} / \mathrm{HeNTac}$ barriermaintained mice. J Clin Microbiol 48: 1908-1910.

19. Cacioppo LD, Turk ML, Shen Z, Ge Z, Parry N, Whary MT, Boutin SR, Klein HJ, Fox JG (2012) Natural and experimental Helicobacter pullorum infection in Brown Norway rats. J Med Microbiol 61: 1319-1323.

20. Shahram B, Javadi A, Mahdi GR (2015) Helicobacter pullorum prevalence in patients with gastroenteritis in humans and chicken in the province of Ardabil in 2014. Indian J Fundamental Appl Life Sci 5: 87-94.

21. Andersen LP (2001) New Helicobacter species in humans. Dig Dis 19: 112-115.

22. Fox JG, Dewhirst FE, Shen Z, Feng Y, Taylor NS, Paster BJ, Ericson RL, Lau CN, Correa P, Araya JC, Roa I (1998) Hepatic Helicobacter species identified in bile and gallbladder tissue from Chileans with chronic cholecystitis. Gastroenterology 114: 755-763.

23. Ceelen LM, Decostere A, Chiers K, Ducatelle R, Maes D, Haesebrouk F (2007) Pathogenesis of Helicobacter pullorum infections in broilers. Int J Food Microbiol 116: 207-213.

24. On SLW, Holmes B, Sackin MJ (1996) A probability matrix for the identification of Campylobacters, Helicobacters and Allied taxa. J Appl Bacteriol 81: 425-432.

25. Gibson JR, Ferrus MA, Woodward D, Xerry J, Owen RJ (1999) Genetic diversity in Helicobacter pullorum and poultry sources identified by an amplified fragment length polymorphism technique and pulsed-field gel electrophoresis. J Appl Microbiol 87: 602-610.

26. Miller KA, Blackall LL, Miflin JK, Templeton JM, Blackall PJ (2006). Detection of Helicabacter pullorum in meat chicken in Australia. Aust Vet J 84: 95-97.

27. González A, Piqueres P, Moreno Y, Cañigral I, Owen RJ, Hernández J, Ferrús MA (2008) A novel real-time PCR assay for the detection of Helicobacter pullorum-like organisms in chicken products. Int Microbiol 11: 203-208

28. Shen Z, Feng Y, Dewhirst FE, Fox JG (2001) Coinfection of enteric Helicobacter spp. and Campylobacter spp. in cats. J Clin Microbiol 39: 2166-2172.

29. Azevedo NF, Almeida C, Fernandes I, Cerqueira L, Dias S, Keevil CW, Vieira MJ (2008) Survival of gastric and enterohepatic Helicobacter spp. in water: Implications for transmission. Appl Environ Microbiol 74: 1805-1811.

30. Sirianni A, Kaakoush NO, Raftery MJ, Mitchell HM (2013) The pathogenic potential of Helicobacter pullorum: possible role for the type VI secretion system. Helicobacter 18: 102111.

31. Parente MR, Monteiro JT, Martins GG, Saraiva LM (2016) Helicobacter pullorum induces nitric oxide release in murine macrophages that promotes phagocytosis and killing. Microbiology 162: 503-512.

32. Yanagisawa N, Geironson L, Al-Soud WA, Ljungh S (2005) Expression of matrix metalloprotease-2, -7 and -9 on human colon, liver and bile duct cell lines by enteric and gastric Helicobacter species. FEMS Immunol Med Microbiol 44: 197204.

33. Burnens AP, Stanley J, Nicolet J (1996) Possible association of Helicobacter pullorum with lesions of vibrionic hepatitis in poultry. In Newell DG, Ketley JM, Feldman RA, editors. Campylobacters, Helicobacters and Related Organisms. New York: Plenum Press. 291-293.

34. Atabay HI, Corry JEL (1997) The prevalence of Campylobacters and Archobacters in broiler chickens. J Appl Microbiol 83: 619-626

35. Ceelen L, Decostere A, On SWL, Van den buluk K, Baele M, Ducatelle R, Haesebrouck F (2006) Helicobacter pullorum in chickens, Belgium. Emerg Infec Dis 12: 263-267.

36. Zanoni RG, Rossi M, Giacomucci D, Sanguinetti V, Manfreda G (2007) Occurrence and antibiotic susceptibility of Helicobacter pullorum from broiler chickens and commercial laying hens in Italy. Int J Food Microbiol 116: 168-173.

37. Zanonia RG, Piva S, Rossi M, Lucchi FA, De Cesare A, Manfreda G (2011) Occurrence of Helicobacter pullorum in turkeys. Vet Microbiol 149: 492-496.

38. Manfreda G, Parisi A, Lucchi A, Zanoni RG, De Cesare A (2011) Prevalence of Helicobacter pullorum in conventional, organic, and free range broilers and typing of isolates. Appl Environ Microbiol 77: 479-484.

39. Wai S, Saleha A, Zunita Z, Hassan L, Jalila A (2012) Occurrence of co-infection of Helicobacter pullorum and Campylobacter spp. in broiler and village (indigenous) chickens. Pak Vet J 32: 503-506.

40. Beren KB, Seyyal AK (2013) Investigation of Helicobacter pullorum occurrence in chicken in the Marmara region of Turkey. Istanbul Üniversity Veteriner Fakultesi Dergisi 39: 6366.

41. Jamshidi A, Bassami MR, Salami H, Mohammadi S (2014) Isolation and identification of Helicobacter pullorum from caecal content of broiler chickens in Mashhad, Iran. Iran J Vet Res 15: 179-182. 
42. Sergeant MJ, Constantinidou C, Cogan TA, Bedford MR, Penn CW, Pallen MJ (2014) Extensive microbial and functional diversity within the chicken cecal microbiome. PLoS One 9: e91941.

43. Svobodova I, Boribova G (2003) Incidence of Helicobacter pullorum and Campylobacter spp. in healthy broilers in the Czech Republic. Zoo Public Health 54: 75.

44. Pilon C, Prouzel-Mauléon V, Ménard A, Mégraud F (2005) Development of real-time quantitative PCR specific to Helicobacter pullorum. In Korolik V, Lee A, Mitchell H, Mendez G, Fry B, Coloe P (Ed.), Abstracts of scientific presentations: 13th International Workshop on Campylobacter, Helicobacter and Related Organisms (CHRO): (pp. 62). Australia. Gold Coast, Queensland.

45. Mohamed MA, Ragab SI, Shahata MA, El-Refaie EM (2010) Helicobacter pullorum among poultry in Assiut-Egypt: Genetic characterization, virulence and MIC. Int J Poult Sci 9: 521-526.

46. Hassan AK, Shahata MA, Refaie EM, Ibrahim RS (2014). Pathogenicity testing and antimicrobial susceptibility of Helicobacter pullorum isolates from chicken origin. Int J Vet Sci Med 2: 72-77. doi: 10.1016/j.ijvsm.2013.12.001.

47. Aboutaleba N, Kuijper E, van Dissela J (2014) Emerging infectious colitis. Curr Opin Gastroenterol 30: 106-115.

48. Burnens AP, Stanley J, Morgenstern R, Nicolet J (1994) Gastroenteritis associated with Helicobacter pullorum Lancet 344: 1569-1570.

49. Steinbrueckner B, Hearter G, Pelz K, Weiner S, Rump JA, Deissler W, Bereswill S, Kist M (1997) Isolation of Helicobacter pullorum from patients with enteritis. Scand J Infec Dis 29: 315-318.

50. Tee W, Montgomery J, Dyall-Smith M (2001) Bacteremia caused by a Helicobacter pullorum-like organism. Clin Infect Dis 33: 1789-1791.

51. Veijola L, Nilsson I, Halme L, Abu Al-Soud W, Mäkinen J, Ljungh A, Rautelin H (2007) Detection of Helicobacter species in chronic liver disease and chronic inflammatory bowel disease. Ann Med 39: 554-560.

52. Ananieva O, Nilsson I, Vorobjova T, Uibo R, Wadström T (2002) Immune responses to bile-tolerant Helicobacter species in patients with chronic liver diseases, a randomized population group, and healthy blood donors. Clin Diagn Lab Immunol 9: 1160-1164.

53. Rocha M, Avenaud P, Menard A, Le Bail B, Balabaud C, Bioulac-Sage P, deMagalhães Queiroz DM, Mégraud F (2005)
Association of Helicobacter species with hepatitis C cirrhosis with or without hepatocellular carcinoma. Gut 54: 396-401.

54. Castera L, Pedeboscq A, Rocha M, Le Bail B, Asencio C, de Lédinghen V, Bernard PH, Laurent C, Lafon ME, Capdepont M, Couzigou P, Bioulac-Sage P, Balabaud C, Mégraud F, Ménard A (2006) Relationship between the severity of hepatitis $\mathrm{C}$ virus-related liver disease and the presence of Helicobacter species in the liver: a prospective study. World J Gastroenterol 12: 7278-7284.

55. Apostolov E, Al-Soud WA, Nilsson I, Kornilovska I, Usenko V, Lyzogubov V, Gaydar Y, Wadström T, Ljungh A (2005) Helicobacter pylori and other Helicobacter species in gallbladder and liver of patients with chronic cholecystitis detected by immunological and molecular methods. Scand J Gastroenterol 40: 96102

56. Karagin PH, Stenram U, Wadström T, Ljungh Å (2010) Helicobacter species and common gut bacterial DNA in gallbladder with cholecystitis. World J Gastroenterol 14: 4817 4822.

57. Ponzetto A, Pellicano R, Leone N, Cutufia MA, Turrini F, Grigioni WF, D'Erricoc A, Mortimer P, Rizzetto M, Silengo L (2000) Helicobacter infection and cirrhosis in hepatitis C virus carriage: is it an innocent bystander or a troublemaker? Med Hypotheses 54: 275-277.

58. Casswall TH, Németh A, Nilsson I, Wadström T, Nilsson $\mathrm{OH}$ (2010) Helicobacter species DNA in liver and gastric tissues in children and adolescents with chronic liver disease. Scand J Gastroenterol 45: 160-167.

59. Andersson R, Kornilovska I, Melin T, Ljungh AH (2002). Helicobacter pullorum and Mycobacterium paratuberculosis in inflammatory bowel disease. Gut 51: 1215.

60. Bohr URM, Primus A, Zagoura A, Glasbrenner B, Wex T, Malfertheiner PA (2002) Group specific PCR assay for the detection of Helicobacteraceae in human gut. Helicobacter 7: 378-383.

\section{Corresponding author}

Wafaa A. Abd El-Ghany

Poultry Diseases Department, Faculty of Veterinary Medicine, Cairo University Giza, Egypt (12211)

Tel: +0201224407992

Email: wafaa.ghany@yahoo.com

Conflict of interests: No conflict of interests is declared. 